\title{
Problema da Clique Corrompida: Teoria de Grafos na Análise de Clusters de Genes ${ }^{1}$
}

\author{
Aimeé dos S. Reis* Poly Hannah da Silva Simone Dantas \\ Universidade Federal Fluminense \\ 24020-140, Campus Valonguinho, Niterói, RJ \\ E-mail: aimeereis@id.uff.br / poly_hannah@id.uff.br / sdantas@im.uff.br
}

\begin{abstract}
RESUMO
Os avanços da biotecnologia permitem pesquisas que medem o nível de expressão de milhões de genes simultaneamente nas diferentes condições e tempo. O gene é um segmento de uma molécula de DNA que contém um código de informações necessárias para a produção de proteínas. Analisar grandes quantidades de genes é uma tarefa difícil, por isso um dos métodos de pesquisa provém da análise e agrupamento dos genes que se manifestam com padrões de expressões similares.

Pequenos vetores medem o nível de expressão dos genes em $n$ tempos diferentes. Esses dados são transformados nas matrizes de intensidade que permitem aos biólogos perceber como as funções dos genes podem ser relacionadas. Os dados são representados como pontos no espaço n-dimensional. Calculando-se a distância euclidiana entre cada dois genes, constrói-se uma matriz de distância dos genes (Figura 1). Genes com distâncias pequenas, os quais partilham as mesmas características e podem ser relacionados funcionalmente, são vistos na formação de clusters (grupos). Existem algumas técnicas de análise da formação de clusters, uma delas é baseada na teoria dos grafos. O modelo que estudamos a seguir foi proposto em [1].

Um grafo $G(V, E)$ é um conjunto finito não-vazio $V$ e um conjunto $E$ de pares nãoordenados de elementos distintos de $V$. Uma clique de um grafo $\mathrm{G}(V, E)$ é um subconjunto $S$ de $V$ tal que $G[S]$ é completo. Fixando um $\theta$ que delimitará a distância entre os genes e utilizando a matriz de distância, podemos construir o grafo de distâncias: associamos um vértice para cada gene; e para cada par de genes, se a distância entre eles for menor que $\Theta$, desenhamos uma aresta entre eles (Figura 1). Desse modo, no grafo de distâncias as cliques representam clusters. O grafo de cliques é um grafo onde cada componente é um grafo completo.

Um grafo pode ser transformado em um grafo de cliques, removendo-se ou incluindo-se arestas, conforme a Figura 2. Este é o chamado Problema da Clique Corrompida, cuja principal pergunta é: dado um grafo $G$, qual seria o menor número de arestas inseridas e removidas para transformar $G$ num grafo de cliques? Este problema foi provado ser NP-Difícil e existem algumas Heurísticas para resolvê-lo [1].

Neste trabalho, estudamos o problema para as classes de grafos: caminhos e ciclos. Uma sequência de vértices $v_{1}, \ldots, v_{k}$ tal que $\left(v_{j}, v_{j+1}\right) \in E, 1 \leq j \leq(k-1)$ é denominado caminho de $v_{1}$ a $v_{k}$,conforme a Figura 2. Um ciclo é um caminho $v_{l}, \ldots, v_{k}$, sendo $v_{l}=v_{k}$ e $k \geq 4$. Definimos como custo a soma do número de arestas removidas com o número de arestas inseridas necessárias para transformar o grafo em um grafo de cliques.

A técnica que nós desenvolvemos para a resolução do problema consiste em particionar o grafo formando grupos de dois vértices, e apenas um grupo de três vértices no caso ímpar. Comparamos nossos resultados com a heurística CAST [1], muito conhecida na literatura. Tal heurística particiona o grafo formando grupos de três vértices e apresenta para
\end{abstract}




\begin{tabular}{|c|c|c|c|}
\hline & Tempo X & Tempo Y & Tempo Z \\
\hline Gene 1 & 1 & 1 & 2 \\
\hline Gene 2 & 3 & 1 & 2 \\
\hline Gene 3 & 1 & 2 & 2 \\
\hline Gene 4 & 2 & 1 & 2 \\
\hline
\end{tabular}

(a)

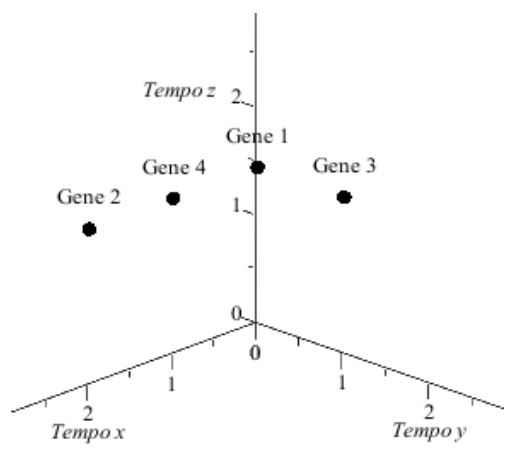

\begin{tabular}{|l|c|c|c|c|}
\hline & Gene 1 & Gene 2 & Gene 3 & Gene 4 \\
\hline Gene 1 & 0 & 2 & 1 & 1 \\
\hline Gene 2 & 2 & 0 & 2,2 & 1 \\
\hline Gene 3 & 1 & 2,2 & 0 & 1,4 \\
\hline Gene 4 & 1 & 1 & 1,4 & 0 \\
\hline
\end{tabular}

(c)

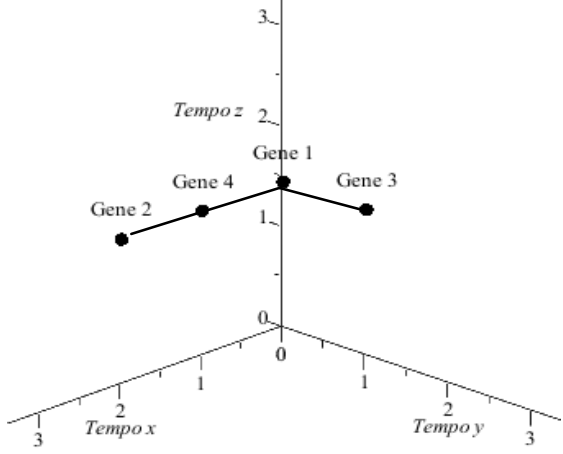

(d)

Figura 1: (a) Matriz de intensidade; (b) Gráfico de distâncias; (c) Matriz de distâncias; (d) Grafo de distâncias $\operatorname{com} \Theta=1$.

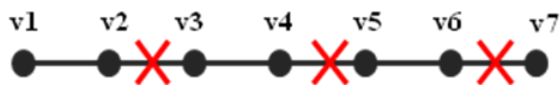

Figura 2: Caminho sendo transformado em cliques de tamanho 2.

caminhos um custo de $\frac{2 n}{3}-1$, se $n=3 k$; e de $2\left\lfloor\frac{n}{3}\right\rfloor$, se $n=3 k+1$ ou $2\left\lfloor\frac{n}{3}\right\rfloor$, se $n=3 k+2$. Para ciclos, apresenta um custo de $\frac{2 n}{3}$, se $n=3 k$; e de $\left\lfloor\frac{2 n}{3}\right\rfloor+1$, se $n=3 k+1$ ou $2\left\lfloor\frac{n}{3}\right\rfloor+1$, se $n=3 k+2$.

Descrevemos a seguir a nossa técnica desenvolvida. Para caminhos, se $n$ for par, devemos retirar as arestas $(2 i, 2 i+1), 1 \leq i \leq \frac{n}{2}-1$, tendo custo $\frac{n}{2}-1$. Se $n$ for ímpar, devemos retirar as arestas $(2 i, 2 i+1), 1 \leq i \leq\left\lfloor\frac{n}{2}\right\rfloor-1$ e incluir a aresta $(n-2, n)$, apresentando custo total $\left\lfloor\frac{n}{2}\right\rfloor$. No estudo dos ciclos, para todo $n$ par, devemos remover a aresta $(1, n)$ e as arestas $(2 i, 2 i+1)$, $1 \leq i \leq\left\lceil\frac{n}{3}\right\rceil$, tendo custo $\left\lceil\frac{n}{3}\right\rceil+1$. Para todo $n$ ímpar, devemos remover a aresta $(n, 1)$, as arestas $(2 i, 2 i+1), 1 \leq i \leq\left\lfloor\frac{n}{3}\right\rfloor$ e inserir a aresta $(n-2, n)$, apresentando custo total $\left\lfloor\frac{n}{3}\right\rfloor+2$. Desta forma, exibimos um custo menor que a heurística CAST. Por exemplo, considere um ciclo de 3858 vértices $(n=3858)$, a heurística tem um custo total de 2572 e a nossa fórmula tem um custo total de 1287 , apresentando uma economia de 1285 arestas.

Palavras-chave: Matemática Discreta, Teoria dos Grafos, Clique, Clusters de Genes.

\section{Referências}

[1] A. Ben-Dor, R. Shamir, Z. Yakhini. Clustering Gene Expression Patterns, Journal of Computational Biology, vol. 6, pp. 281-297, (1999).

[2] J. A. Bondy and U. S.R. Murty, "Graph Theory with applications", University of Waterloo, Canada, 1976. 